\title{
Risk-tourism, risk-taking and subjective well-being: A review and synthesis
}

\author{
Michelle R. Holma* \\ michelle.holm@ucf.edu \\ Peter Lugosib \\ Robertico R. Croes ${ }^{\mathrm{a}}$ \\ Edwin N. Torres ${ }^{a}$ \\ aRosen College of Hospitality Management, University of Central Florida, 9907 Universal \\ Boulevard, Orlando, FL 32819, USA \\ bOxford School of Hospitality Management, Faculty of Business, Oxford Brookes University, \\ Gipsy Lane, Oxford, OX3 0BP, UK \\ $*$ Corresponding author
}

\begin{abstract}
This paper seeks to conceptualize the potential relationship between subjective well-being and risk-taking within 'risk-tourism' i.e. specific activities that involve the potential for physical injury and death and require participants to develop competencies with which to overcome the risks associated with those activities. Literature is reviewed in three fields of inquiry: subjective wellbeing, with specific reference to the interactions between wellbeing and tourism behavior, risktaking in tourism and risk-tourism. The areas of interaction between risk-tourism and subjective well-being, emerging critical questions and potential areas of future inquiry are subsequently examined.
\end{abstract}

\section{Keywords:}

Tourism, risk, risk-tourism, subjective well-being, edgework, leisure

\section{Highlights:}

-Conceptualizes relationship between risk-taking in tourism and subjective well-being. -Reviews literature on subjective well-being, risk-taking in tourism and risk-tourism. -Identifies methodological limitations of existing risk-tourism and well-being studies. -Proposes new lines of enquiry integrating risk-tourism and subjective well-being.

Published as:

Holm, M., Lugosi, P., Croes, R. and Torres, E. (2017) Risk-tourism, risk-taking and subjective well-being: A review and synthesis. Tourism Management, 63, 115-122. DOI:

10.1016/j.tourman.2017.06.004.

(Please consult the final published version if citing) 


\section{Introduction}

There is growing interest among scholars in risk-taking within tourism and leisure consumption (Berdychevsky \& Gibson, 2015a, 2015b, 2015c; Lepp \& Gibson, 2008; Uriely \& Belhassen, 2006). This body of work sought to explore tourists' conceptions of risk, their motivations for risk-taking as well as their management of risk(s). It is possible to argue that risk is inherently part of all tourism experiences (see e.g. Elsrud, 2001; Larsen \& Brun, 2011); however, with extreme forms of tourism, which we refer to as 'risk-tourism', involving thrill seeking, physical exertion and the possibility for physical harm, risk-taking is a core aspect of the tourism experience and a key reason for participation (Allman, Mittelstaedt, Martin, \& Goldenberg, 2009; Lipscombe, 1999). Risk tourism has arguably evolved into its own niche of special interest tourism as it has become a widely recognized activity in the $21^{\text {st }}$ century across multiple destinations (Allman et al., 2009; Buckley, 2012; Hallin \& Mykletun, 2006). The current paper contributes to contemporary debates on risk by conceptualizing the link between risk-tourism and one particular outcome for participants - subjective well-being (SWB).

To date, limited research has associated SWB with risk-taking within risk-tourism (as a distinct type of activity), and the emphasis has been on psychological wellbeing during peak experiences rather than as a longer-term impact or state of being (cf. Csikszentmihályi, 2000). Importantly, the concepts of risk-taking in risk-tourism activities and SWB are frequently found in two separate domains of literature. In an attempt to connect the concepts, the purpose of this review and synthesis is two-fold: (1) to offer a critical overview of the literature on conceptualizations of risk and SWB, with particular reference to risk-tourism and leisure behavior; and (2) to uncover whether or not common attributes exist between the concepts of risk and SWB in a tourism context. The rationale behind conducting this review and synthesis is to provide a conceptual reference point to inform future empirical and theoretical research to determine tourists' level of SWB after having partaken in risky activities while on vacation. Additionally, the present research aims to shed light on key short and long-term outcomes of tourism-related risktaking, which may also help to uncover the motivations for engaging in risk activities and to conceptualize how the notions of risk are conceived and/or managed by 'risk tourists' (e.g. consumers engaged in high-risk tourism-activities).

The review is based on a purposive sample of the literature from three subject areas: 1) subjective well-being; 2) risk/edgework; and 3) special interest tourism, specifically 'risktourism'. Various researchers agree that risk-tourism is a sub-niche of adventure tourism, which is itself considered a type of special interest tourism (SIT) (Allman et al., 2009; Bentley and Page, 2001; Trauer, 2006). The primary source of literature was EBSCO's Hospitality and Tourism Complete (HTC) online database. Additional references were also extracted through EBSCO's Business Source Premier, ABI/Inform (ProQuest) and Google Scholar. However, HTC was chosen above other platforms for two reasons: (1) it is better focused on tourism and leisure literature than wider social science, psychology or business databases; (2) the HTC database indexes a wider range of journals that may contain tourism-related topics, including the leisure field, than other premium databases such as Scopus or Thomson Reuters' Web of Knowledge.

The search utilized the terms: 'subjective well-being', 'well-being', 'risk', and 'risk tourist', in combination and as stand-alone terms. The search period was limited to between 1970 and 2016. The initial cut-off point of the 1970s was deemed appropriate because the original conceptualizations of subjective well-being emerged during that time. Concepts such as 'wellbeing' are increasingly being utilized by tourism researchers (see Hartwell, Fyall, Willis, Page, Ladkin, \& Hemingway, In-press), and the term identified a wide and growing body of literature. 
Similarly, the term 'risk tourist' yielded several hundred results but the majority were not related to the foundational premise and scope of this study, as they covered areas such as risk assessments of destinations, security, insurance, medical travel and travel safety (see e.g. Page, 2009). It was therefore important to use the combination of terms to reduce and order the data. This sorting and screening process yielded a final usable sample of 49 key articles, which underpin this review.

A review of the literature revealed that the concept of risk is abstract and widely deployed in tourism studies; but, more importantly, it highlighted that existing links between tourism and risk-taking remain under-conceptualized, despite a growing interest in the common attributes between the two domains. For purposes of this paper, a 'risk tourist' is an individual who partakes in extreme or high-consequence risk activities while on vacation (Elsrud, 2001). One example of a high-consequence risk activity would be BASE jumping, where failure to execute the activity correctly could result in injury or death (Allman et al., 2009).

Some researchers have associated risk-taking with negative outcomes. Bentley and Page (2001) and Bentley, Page and Edwards (2008) argued that individuals who engaged in risk activities in a particular destination and were injured as a result of the activity, or were with someone who had died, also tended to have negative associations with the destination. Conversely, other scholars have found that the 'outcome' perceptions of risk tourism and risk activity to be entirely positive, as the activities that 'risk-inclined' individuals partake in cause positive emotional and/or cognitive states in those individuals (Johnston, 1992; Lyng, 1990; Lipscombe, 1999; Lupton \& Tulloch, 2002; Han \& Patterson 2007; Allman et al., 2009). However, as noted at the outset, research associating risk-behavior and positive states focused on the peak experience rather than the longer-term impacts of risk-taking behavior on SWB (Csikszentmihályi, 2000, 2014).

SWB can also be considered an abstract concept, but it has been widely researched in a variety of literature streams. In the tourism literature, the concept of SWB spun off from its parent concept, quality of life (QOL). In the past, QOL was considered an objective measureable outcome (Michalkó \& Rátz, 2010); however, current literature has identified SWB as a subjective dimension of QOL (Vittersø, 2004; Moscardo, 2009; Michalkó \& Rátz, 2010; Rivera, Croes, \& Lee, 2016; Croes, 2016). Moreover, the definition of SWB as a concept remains ambiguous (Michalkó \& Rátz, 2010). As a result, it has been challenging for scholars to measure SWB from subjects' perspective because individuals are frequently required to self-report/assess (Shin \& Johnson, 1977), thereby resulting in a less objective assessment. Regardless of the measure used, the most common attributes of SWB have been identified as happiness and/or satisfaction with life (Diener, 1994; 1996).

The following section presents a holistic assessment of SWB, before considering the interactions between SWB and risk in tourism. Subsequent sections review the concept of risk as it relates to risk activity and risk tourism. The final section of this paper synthesizes the concepts and themes that emerged from the review of the literature in order to evaluate areas of congruity that may inform future inquiry.

\section{Subjective Well-Being, Tourism and Leisure}

One of the first scholars to examine life satisfaction was Campbell (1976). His research measured various characteristics that may influence life satisfaction (e.g. life cycle, occupation, religion, sex, etc.). Over time, SWB evolved out of Quality of Life (QOL) as a distinct concept, and became a subjective measurement of well-being (see e.g. Eid \& Larsen, 2008; Emmons, 1986; Ryff, 2014; Tennant, Hiller, Fishwick, Platt, Joseph, Weich, Parkinson, Secker, \& Stewart-Brown, 
2007). By definition, "QOL refers to one's satisfaction with life, and feelings of contentment or fulfillment with one's experience in the world" (Andereck, Valentine, Vogt, \& Knopf, 2007, p. 484). Moscardo (2009) defined QOL "as the notion of human welfare (well-being) measured by social indicators rather than by 'quantitative' measures of income and production [...and] is often seen as equivalent to subjective well-being” (p. 161). Michalkó and Rátz (2010) established that "the subjective aspect of one's quality of life is usually assessed through a person's perceived satisfaction with their own life" (p. 35).

One of the pioneers to link SWB to life happiness was Diener (1994) who explored life satisfaction on an emotional and cognitive level, and further indicated that conceptualizations of SWB consist of three "hallmarks": (1) it is subjective, residing in the individual experience; (2) it utilizes positive rather than negative measures; and (3) it is a global assessment of one life domain. Moreover, Diener (1994) posited that "a person who has pleasant emotional experiences is more likely to perceive his or her life as being desirable and positive" (p. 107). As such, SWB is not only composed of cognitive components, such as happiness, but also experiences, which have the potential to influence the stability of the concept (Diener, 1994). The definitions of SWB have been contested over the years, as have the measurements used to evaluate an individual's happiness (Eid \& Larsen, 2008). In an effort to stabilize the concept, some researchers have plainly stated that happiness "should be viewed as a global assessment of a person's quality of life according to his own chosen criteria" (Shin \& Johnson, 1978, p. 478). Ultimately, happiness has been shown to emerge from satisfaction with life (Diener, Oishi, \& Lucas, 2003), and is the ontological assumption of SWB that will underlie the current review and synthesis.

Psychologists have focused extensively the role of personality in shaping subjective wellbeing (cf. Schmutte, \& Ryff, 1997; Ryff, 2014). However, researchers have acknowledged that personality alone does not determine or explain SWB and factors such as culture, relationships and social activities can also influence perceptions of it (cf. Butt, Rashid, Mahanoor, Saeed, Adnan, \& Hashmi, 2016; Diener et al., 2003; Ryff \& Keyes, 1995; Ryff, 2014). Diener (1996) also argued that personality may not be a direct predicator of SWB, but rather, it impacts SWB based on the following attributes: heritability, temperament dispositions, environmental variables, perceived social support and coping style. For instance, life cycle events were found to have a low correlation with an individual's well-being because people tend to adapt and return to their baseline, which is set by their temperament. In turn, "at the emotional level, people react to the activities in which they are involved and to life events with pleasant affect (e.g. joy and affection) and with unpleasant affect (e.g. anxiety and grief)" (Diener, 1996, p. 390). Since SWB is typically measured as a longterm condition, and not as a state of momentary affect, personality traits alone are not sufficient to understand the underlying variability of SWB between different individuals (Diener, 1996).

Within a tourism context, well-being and QOL have been explored from two viewpoints (Dolnicar et al., 2012): (1) from the viewpoint of the destination resident (Andereck et al., 2007; Henderson, 2007; Moscardo, 2009; Cecil, Yao-Yi, Suosheng, \& Avgoustis, 2010; Michalkó \& Rátz, 2010; Rivera, Croes, \& Lee, 2016 ), and (2) from the viewpoint of the tourist (Neal, Sirgy, \& Uysal 2004; Neal, Uysal, \& Sirgy, 2007; Michalkó \& Rátz, 2010). For purposes of the current review, Neal et al. (2004) affirmed that QOL is most affected by a tourist's satisfaction with travel experiences and leisure life, and that 'length of stay' directly correlates with satisfaction. However, there remains a need, and an opportunity, to examine how tourists' perceptions of risk-taking can ultimately lead to their satisfaction, whether in a temporally confined, or long-term state. In order to evaluate the potential for linkages between risk and SWB in the aforementioned areas, the next 
section reviews the concept of risk, initially as a general concept, but it primarily focuses on evaluating it within the parameters of tourism and leisure.

\section{Risk, Tourism and Leisure}

From a general perspective, the conceptualizations of risk activity have commonly drawn upon Maslow's notion of 'peak-experience' (Csikszentmihályi, 2000, 2014; Lipscombe, 1999; Ryan, 2004). Brymer and Oades (2009) for example, tie Maslow's peak-experience to risk-related activity, positing that "certain events that bring us nearer to the reality of our deaths are positive life-changing experiences [such as humility \& courage]" (p. 115). Maslow identified 19 characterizations of the 'peak-experience', some of which include: awareness of the absolute, total attention, experience/object unification, and experience is intrinsically perfect (Brymer \& Oades, 2009). In short, peak experiences are emotionally, cognitively and often physically engaging, requiring the skillful deployment of competencies, and are thus intensively immersive.

As it relates to tourism and leisure, the findings of the current review most commonly rooted 'risk activity' in adventure tourism (Bentley \& Page, 2001; Elsrud, 2001), where 'adventure tourism' was found to be situated in special interest tourism (SIT) (Trauer, 2006). From a theoretical perspective, SIT evolved out of the Tourism Interest Continuum. Contrary to general interest tourism (GIT) and mixed interest tourism (MIT), the special interest tourist decides where to go based on the interest/activity they want to pursue and where it can be pursued (i.e. the destination or location). Early categorizations of special interest tourists were primarily related to cultural tourists, sport tourists, and eco-tourists. It was not until more recently that the category expanded to tourists who are also soft or novice leisure participants who engage in risk activity. These leisure participants may be considered sub-segments of serious leisure tourists (cf. Stebbins, 2007). Serious leisure tourists also encompass those who participate in activities like skydiving, rock climbing, or mountaineering, and while the activities can be perceived as 'risky', they are categorized as a subset of adventure tourism (Trauer, 2006).

In describing adventure tourism, Trauer (2006) explains that "the adventure recreationist moves along a continuum from introduction through development to commitment as he/she gains more experience with the activity" (p. 195). Adventure tourists and risk tourists are oftentimes the same subset of the population of serious leisure tourists. Thus, risk tourists, like adventure tourists, tend to become more committed to the activity as they gain experience. Not all adventure tourism related activities include risk, but some of the activities are risky. Therefore, adventure tourists should not be labeled as risk-tourists, rather the literature labels adventure tourists who engage in high-risk activities as 'edgeworkers' (Lyng, 1990).

Lyng (1990) first introduced edgework to understand the reasoning behind why an individual would partake in activities that could negatively affect their life, and potentially result in death (see also Lyng, 2005). Edgework is defined as "experience ... in which the individual's failure to meet the challenge at hand will result in death, or at the very least, debilitating injury" (Lyng, 1990, p. 857). Those activities classified under 'edgework' include: hang gliding, skydiving, scuba diving, rock climbing, motorcycle racing/car racing, downhill ski racing, excessive alcohol or drug use, gambling and sex tourism (Lyng, 1990; Uriely \& Belhassen, 2006; McCabe et al., 2010). 'Extreme sports' are another form of edgework, which are defined by Allman et al. (2009, p. 232) as: "activities in which accidents or mistakes will commonly result in severe injury or death". Those activities include BASE jumping, along with other types of sports broadcasted during the publically recognized X-Games (Allman et al., 2009) including: skateboarding, dirt-biking, snowboarding, ski-jumping (ESPN.go.com, 2012), waterfall kayaking, 
extreme mountaineering, solo rope-free climbing (Brymer \& Oades, 2009), bungee jumping, and caving (Bentely \& Page, 2001).

Engagement in edgework leads to growing competency, resulting in a sense of achievement and changing perceptions of and attitudes towards risk (Csikszentmihályi, 2000; Priest \& Bunting, 1993; Priest \& Carpenter, 1993). This has a number of implications for this study. First, it highlights that evaluations of risk activities or events are subject to human interpretation and are negotiable through participants' agency (Mitchell, 1999), which challenges the empirical usefulness of dividing between 'real' or objective risks and subjective perceptions of risk. Second, to bring the scope of risk activities back to the current review and how partaking in those activities relate to SWB, Allman et al. (2009) identified three derivatives of risk-aversive portrayal (selfimprovement, emotional engagement, and control) in order to explain why risk inclined individuals view risk as positive.

Cater (2006) argued that risk tourists really seek thrills, which hints at alternative connections to tourists' SWB: perceived risk may be negated by the 'thrill' that risk-inclined individuals feel. For instance, the positive emotion felt after the activity may in fact override the negative perception of the activity prior to engagement, thereby serving as motivation to participate in the activity again, especially after engaging without a negative outcome. Importantly, risk-taking in traveling is said to mean an "'active courting of risk', rather than responses to 'highconsequence risk" (Elsrud, 2001, p. 602). This helps to distinguish between risk tourism as a specific domain of tourist practice, as opposed to the general management of risks encountered within tourism, leisure and travel.

It should be noted that another term used to describe the risk dimensions of tourism and leisure activities is 'sensation-seeking'. According to Pizam, Jeong, Reichel, van Boemmel, Lusson, Steynberg, and Montmany (2004) the term sensation-seeking has been used "to describe the trait that includes a variety of risk-taking and sensation seeking behaviors and the expressed intolerance for boredom" (p. 253). Likewise, Lepp and Gibson (2008) posited that sensationseeking was closely associated to novelty-seeking behaviors. Moreover, the four dimensions of novelty-seeking behaviors as identified by Lee and Crompton (1992) are: thrill, change from routine, boredom alleviation and surprise. Travelers who scored higher on a sensation-seeking scale were more prone to travel internationally and were more likely to explore destinations that might be deemed riskier by the general population (Lepp \& Gibson, 2008). Reisinger and Mavondo (2005) studied various factors that affected individuals' likelihood to travel internationally. The authors concluded that, "culture, personality, and motivation to travel had significant influence on the perceptions of travel risk, anxiety, and safety" (p.222). Torres (2016) argued that people travel in part to experience activities different from those they do at home. Torres (2016) concluded that "travel brings forth a heightened sense of awareness of the brevity of the present. This led individuals to experience what some called 'FOMO', or the fear of missing out. Encouraged by other travelers, fearing missing out, and seeking to forge a new identity, individuals became more open to various travel experiences, even if they were perceived to be slightly risky" (p. 2148). In short, risk-taking activities were seen as drivers for and thus underpinning positive outcomes.

Thus far, risk has been described from the perspective of categorization (i.e. in relation to adventure tourism), and motivation and outcome (regarding sensation-seeking and noveltyseeking behaviors). Alternatively, some researchers also included a broader contextual approach to risk activity, conceptualizing it as 'deviant' consumer behavior and seeking to account for the factors that shape where and how it emerges. For example, Ryan and Kinder (1996) studied sex 
tourism and argued that it is a "temporarily constrained, socially tolerated period of wish fulfillment, a form of fantasy enhancement that is normally denied to people" (p. 507). As such, individuals traveling on vacation might engage in activities that might seem 'out of character' at home. For example, Berdychevsky and Gibson's (2015a; 2015b; 2015c) research on young women's sexual risk-taking indicated that, "SRT [sexual risk-taking] is more prevalent, probable, and frequent in certain types of tourist experience" (2015c, p. 303). Berdychevsky and Gibson (2015b, 2015c) explain that the anonymity offered by their tourist status, the lack of judgment, the possibility of enacting fantasies not available at home, the pursuit of risk itself, and the detachment from social norms underpinned risk-taking behavior.

Similarly, Uriely and Belhassen (2006) assessed the use of drugs in a tourism context and concluded that tourist 'status' protected them, and to a certain degree, legitimized their behaviors while in a foreign country. It should be noted that the participants' risk-taking activities were not deemed completely reckless, as certain precautions are often taken by tourists to minimize harm to self and others, however their study further illustrates how risk-taking behavior while on vacation made the participants feel positively about participating in the activity, regardless of the negative perception surrounding the activity. Importantly for this review, the issue of risk context emphasized the impacts of the risk-taking behavior in situ, thus highlighting the need to examine how risk-taking may affect upon psychological states beyond the tourism context, in consumers' 'everyday' lives.

To this point, the current study has presented a review of the literature from two distinct concepts: SWB and Risk. Prior to investigating the connections between the constructs in the section that follows, a comprehensive survey of published works examining SWB, risk activity, and risk tourism (Table 1) is presented. It is important to note that these have remained distinctly independent bodies of work thus far, and explicit connections between SWB and risk-taking behavior will be formulated in the following section.

Table 1: Core themes within existing conceptualizations of key constructs

\begin{tabular}{|c|c|}
\hline \multicolumn{2}{|c|}{ Subjective Well-Being } \\
\hline Author(s) & Core themes \\
\hline Campbell (1976) & $\begin{array}{l}\text { Goal to expand the definition beyond happiness and life satisfaction in } \\
\text { order to identify the major dimensions of the experience of well-being. }\end{array}$ \\
\hline Emmons (1986) & $\begin{array}{l}\text { SWB consists of three primary components: positive affect, negative } \\
\text { affect, and life satisfaction (p. 1058). }\end{array}$ \\
\hline Diener (1994) & $\begin{array}{l}\text { Humans are not only capable of appraising events, life circumstances, } \\
\text { and themselves, but they make such appraisals continuously (p. 106- } \\
\text { 107). }\end{array}$ \\
\hline Diener (1996) & $\begin{array}{l}\text { SWB comprises people's evaluative responses to their lives - both } \\
\text { cognitive and emotional responses (p. 390). }\end{array}$ \\
\hline Vittersø (2004) & $\begin{array}{l}\text { SWB comprises people's evaluative responses to their lives [-] usually } \\
\text { denoted "satisfaction" (p. 299). }\end{array}$ \\
\hline
\end{tabular}




\begin{tabular}{|c|c|}
\hline Neal et al. (2007) & $\begin{array}{l}\text { SWB is part of the subjective QOL measurement that attempts to } \\
\text { measure the perceived satisfaction that individuals report experiencing } \\
\text { in their lives (p. 154). }\end{array}$ \\
\hline Sirgy (2010) & Life satisfaction/overall happiness in life. \\
\hline $\begin{array}{l}\text { Michalkó and Rátz } \\
\text { (2010) }\end{array}$ & $\begin{array}{l}\text { SWB is influenced to a great extent by the individual's requirements and } \\
\text { expectations: once these are satisfied, they can consider themselves } \\
\text { essentially a happy person (p. } 37 \text { ). }\end{array}$ \\
\hline Dolnicar et al. (2012) & $\begin{array}{l}\text { Happiness. To understand it, it is important to measure the individual's } \\
\text { cognitive and affective reactions to specific domains of life (p. 63). }\end{array}$ \\
\hline \multicolumn{2}{|l|}{ Risk-Activity } \\
\hline $\begin{array}{l}\text { Csikszentmihályi } \\
(2000,2014)\end{array}$ & $\begin{array}{l}\text { Identified key features of flow states in peak experiences: the merging } \\
\text { of action and awareness; the centering of attention on a limited stimulus } \\
\text { field; loss of ego; the control of action and environment; demands for } \\
\text { action and clear feedback (on action); autoleletic nature of flow i.e. } \\
\text { activity having no goals or rewards beyond itself. }\end{array}$ \\
\hline Lyng (1990) & $\begin{array}{l}\text { Some people place a higher value on the experience of risk-taking than } \\
\text { they do on achieving the final ends of the risk undertaking (p. 852). Re- } \\
\text { termed voluntary risk-taking as "edgework". }\end{array}$ \\
\hline $\begin{array}{l}\text { Lee and Crompton } \\
\text { (1992) }\end{array}$ & $\begin{array}{l}\text { Identified four dimensions of novelty seeking behaviors to include: } \\
\text { thrill, change from routine, boredom alleviation, and surprise. }\end{array}$ \\
\hline $\begin{array}{l}\text { Ryan and Kinder } \\
\text { (1996) }\end{array}$ & $\begin{array}{l}\text { Travel presents an opportunity for individuals to engage in behaviors } \\
\text { that would not be allowed at home. }\end{array}$ \\
\hline Lipscombe (1999) & $\begin{array}{l}\text { Defined skydiving as a high-stimulus, high-risk activity - participants } \\
\text { have been described as stimulus addicts, sensation seekers, thrill seekers, } \\
\text { action seekers, and edgeworkers (p. 268). }\end{array}$ \\
\hline $\begin{array}{l}\text { Lupton and Tulloch } \\
\text { (2002) }\end{array}$ & $\begin{array}{l}\text { In voluntary risk-taking, the activity in which individuals engage is } \\
\text { perceived by them to be in some sense risky, but is undertaken } \\
\text { deliberately and from choice (p. 114). }\end{array}$ \\
\hline Allman, et al. (2009) & $\begin{array}{l}\text { Individuals purposefully take risks and are transformed by the common } \\
\text { realization of humility and true courage (p. 230). }\end{array}$ \\
\hline $\begin{array}{l}\text { Brymer and Oades } \\
\text { (2009) }\end{array}$ & $\begin{array}{l}\text { Extreme sports are defined as leisure activities where the most likely } \\
\text { outcome of a mismanaged mistake or accident is death (p. 114). }\end{array}$ \\
\hline
\end{tabular}




\begin{tabular}{|c|c|}
\hline \multicolumn{2}{|l|}{ Risk-Tourism } \\
\hline Wickens (1997) & $\begin{array}{l}\text { Action space }- \text { activities that are consequential, problematic, and } \\
\text { undertaken for what is felt to be their own sake (p. 154). }\end{array}$ \\
\hline $\begin{array}{l}\text { Bentley and Page } \\
(2001)\end{array}$ & $\begin{array}{l}\text { Activities involving a combination of adventure and excitement pursued } \\
\text { in an outdoor environment - during the past decade, adventure tourism } \\
\text { has expanded as a major niche [...] where it is chosen for the risk and } \\
\text { challenge it poses to participants (p. 707). }\end{array}$ \\
\hline Elsrud (2001) & $\begin{array}{l}\text { en taking risks, life is carved out rather than merely lived in the } \\
\text { rints of others (p. 603). }\end{array}$ \\
\hline Ryan (2003) & $\begin{array}{l}\text { The act of risk-taking is undertaken with the view of obtaining a state of } \\
\text { exhilaration, an adrenalin rush, or a state of well-being that will often } \\
\text { have both immediate and possible long-term benefits (p. 56). }\end{array}$ \\
\hline $\begin{array}{l}\text { Reisinger and } \\
\text { Mavondo (2005) }\end{array}$ & $\begin{array}{l}\text { ion of risk in travel include: culture, } \\
\text { l. }\end{array}$ \\
\hline Cater (2006) & Tourists seek thrills rather than risk. \\
\hline Trauer (2006) & $\begin{array}{l}\text { Difficult to define - ambiguous term. Risk tourism is considered a sub- } \\
\text { segment level of adventure tourism. }\end{array}$ \\
\hline $\begin{array}{l}\text { Uriely and Belhassen } \\
(2006)\end{array}$ & $\begin{array}{l}\text { Voluntary risk-taking is a behavior that involves individuals' } \\
\text { participation in activities that they perceive to be in some sense } \\
\text { dangerous, but are undertaken deliberately, and from choice (p. 339). }\end{array}$ \\
\hline $\begin{array}{l}\text { Lepp and Gibson } \\
(2008)\end{array}$ & $\begin{array}{l}\text { king scores were associated with willingness to } \\
\text { hations. }\end{array}$ \\
\hline $\begin{array}{l}\text { Berdychevsky and } \\
\text { Gibson }(2015 \mathrm{a})\end{array}$ & $\begin{array}{l}\text { the perceptions of risks associated with } \\
\text { n setting. }\end{array}$ \\
\hline $\begin{array}{l}\text { Berdychevsky and } \\
\text { Gibson }(2015 b)\end{array}$ & $\begin{array}{l}\text { Some of the motivations for young women engaging in sexual behaviors } \\
\text { during travel included the anonymity offered by their tourist status, the } \\
\text { lack of judgment, the possibility of enacting fantasies not available at } \\
\text { home, the pursuit of risk itself, and the detachment from social norms. }\end{array}$ \\
\hline $\begin{array}{l}\text { Berdychevsky and } \\
\text { Gibson }(2015 \mathrm{c})\end{array}$ & $\begin{array}{l}\text { Examined perceptions of risks associated with sexual behaviors in the } \\
\text { tourism setting. Risks are categorized as: physical or sexual health, } \\
\text { emotional, social, and mental. }\end{array}$ \\
\hline Torre: & $\begin{array}{l}\text { gs about a heightened sense of the brevity of time. This } \\
\text { oupled with the "fear of missing out", and influence of group }\end{array}$ \\
\hline
\end{tabular}


dynamics encourages individuals to engage in riskier activities than they would in their daily routines.

\section{Connecting SWB and Risk in Tourism and Leisure}

Within tourism research, there is relative consistency in definitions of SWB, which was principally rooted in QOL (Neal et al., 2007; Sirgy, 2010; Michalkó \& Rátz, 2010; Dolnicar et al., 2012). More importantly for the current discussion, three common aspects of SWB have emerged from the literature: (1) happiness and life satisfaction; (2) positive and negative affect; and (3) fulfillment of needs and goals (Campbell, 1976; Emmons, 1986; Diener, 1994; Diener, 1996; Vittersø, 2004; Neal et al., 2007; Cecil et al., 2010; Michalkó \& Rátz, 2010; Sirgy, 2010; Dolnicar et al., 2012).

Conversely, there is considerable inconsistency in the definition and deployment of riskactivity and risk-tourism in the literature. Commonality exists in the conceptualization of riskactivity between 2 streams of literature, rooting the concept in Maslow's peak-experience (Lipscombe, 1999; Ryan, 2003). Likewise, commonality exists in conceptions of risk-tourism between 2 alternative streams of literature, rooting the concept in adventure tourism (Bentley \& Page, 2001; Elsrud, 2001). The remaining literature has rooted the concepts of risk activity and risk tourism in other concepts, such as: personality predisposition model and intrinsic motivation model (Lyng, 1990), institutionalized tourist (Wickens, 1997), tourist interest continuum (Trauer, 2006), controlled-decontrolled behaviors (Uriely \& Belhassen, 2006), edgework (Allman et al., 2009), and sensation seeking theory (Brymer \& Oades, 2009), respectively.

Despite the varying definitions and ontological perspectives on risk-activity, risk-tourism, and SWB, the following themes have emerged from the literature and will serve as a basis to identify the common attributes between risk and SWB in tourism and leisure in the final section of this paper (see Table 2). 
Table 2: Emergent Themes

\begin{tabular}{|c|c|c|c|}
\hline & Risk-Activity & Risk-Tourism & Subjective Well-Being \\
\hline Definition & $\begin{array}{l}\text { Participants have been } \\
\text { described as stimulus } \\
\text { addicts, sensation seekers, } \\
\text { thrill seekers, action } \\
\text { seekers, and edgeworkers } \\
\text { (Lipscombe, 1999, p. 268). }\end{array}$ & $\begin{array}{l}\text { Activities involving a combination of } \\
\text { adventure and excitement pursued in an } \\
\text { outdoor environment - during the past } \\
\text { decade adventure tourism has expanded as } \\
\text { a major niche }[. . .] \text { where it is chosen for } \\
\text { the risk and challenge it poses to } \\
\text { participants (Bentley and Page, 2001, p. } \\
\text { 707). }\end{array}$ & $\begin{array}{l}\text { SWB comprises people's evaluative } \\
\text { responses to their lives - both cognitive } \\
\text { and emotional responses (Diener, 1996, } \\
\text { p. 390). }\end{array}$ \\
\hline Meaning & $\begin{array}{l}\text { Edgeworkers are fearless } \\
\text { and spontaneous } \\
\text { individuals who are } \\
\text { inclined toward partaking } \\
\text { in risk activity, sometimes } \\
\text { acting on impulse (Lyng, } \\
\text { 1990). }\end{array}$ & $\begin{array}{l}\text { In defining risk tourism through the SIT } \\
\text { niche of adventure tourism Trauer (2006) } \\
\text { posits that "holidays no longer just } \\
\text { facilitate traditional escape of tourists from } \\
\text { daily living, but rather the search for } \\
\text { personal life fulfillment, happiness, } \\
\text { paradise and has become a highlight of } \\
\text { leisure, part of quality of life" (p. 184). }\end{array}$ & $\begin{array}{l}\text { SWB is not only composed of cognitive } \\
\text { components, such as happiness, but also } \\
\text { experiences, which have the potential to } \\
\text { influence the stability of the concept } \\
\text { (Diener, 1994). }\end{array}$ \\
\hline $\begin{array}{l}\text { Emotional and } \\
\text { cognitive } \\
\text { triggers }\end{array}$ & $\begin{array}{l}\text { Edgework (Lupton and } \\
\text { Tulloch, 2002) }\end{array}$ & $\begin{array}{l}\text { Desire for happiness, growth and life } \\
\text { fulfillment (Trauer, 2006). }\end{array}$ & $\begin{array}{l}\text { Desire for happiness and/or satisfaction } \\
\text { with life (Dolnicar et al., 2012) }\end{array}$ \\
\hline $\begin{array}{l}\text { Methods of } \\
\text { evaluation }\end{array}$ & $\begin{array}{l}\text { Self-assessment/ } \\
\text { subjective measurement } \\
\text { (e.g. Lupton and Tulloch, } \\
\text { 2002) }\end{array}$ & $\begin{array}{l}\text { Self-assessment/ subjective measurement } \\
\text { (e.g. Uriely and Belhassen, 2006) }\end{array}$ & $\begin{array}{l}\text { Self-assessment/subjective measurement } \\
\text { (e.g. Dolnicar et al., 2012) }\end{array}$ \\
\hline Components & $\begin{array}{l}\text { Self-improvement, } \\
\text { emotional engagement, } \\
\text { and control (Allman, et al., } \\
\text { 2009). }\end{array}$ & \begin{tabular}{|lr} 
Sensation-seeking, context & specific \\
activities (Neal, et al., 2004; Trauer, 2006).
\end{tabular} & $\begin{array}{l}\text { Reactions to activities and life events } \\
\text { with pleasant and unpleasant affect } \\
\text { (Diener, } \\
\text { joy/affection/anxiety/grief. }\end{array}$ \\
\hline
\end{tabular}


In order establish the relationship between risk and SWB and identify the common attributes between both concepts, the existing theory base of each concept was explored. Previous research has indicated that the bottom-up theory of life satisfaction is the most prominent theory for explaining SWB, where "overall life satisfaction is determined by satisfaction within major life domains (e.g. leisure, work, health, and family life)" (Neal et al., 2007, p. 154). Neal et al. (2007) validates, from a theoretical perspective, that tourism can contribute to an individual's overall QOL (of which SWB is a dimension).

Comparatively, the goal theory of SWB is "based on the notion that tourists can experience higher levels of subjective well-being (life satisfaction or overall happiness in life) if they select leisure travel goals that have high levels of positive valance and expectancy; that tourists engage in certain actions to implement these goals; and that they engage in actions to experience goal attainment" (Sirgy, 2010, p. 247). This theory utilizes: the goal valance principle where motives, norms, satisfaction, and attainment play a role in expectancy; the goal implementation principle where the tourist has to take action in order to meet their travel goals; and the goal attainment principle where targeted life enhancements/leisure travel goals are enhanced by satisfaction (Sirgy, 2010).

Evidence has shown that people travel for several reasons including, but not limited to, escape, freedom, and to enhance their persona, all of which contribute positively to their wellbeing (McCabe et al., 2010). Furthermore, as evidenced by Han and Patterson (2007), risk activity has been shown to reduce stress, thereby positively impacting the well-being of the individual. To the contrary, travel can also have a negative impact on the tourist's well-being if they had a bad experience, if the cost was too high, or if they were feeling depressed upon return from their vacation (Moscardo, 2009). To understand the potential SWB of risk tourists, it is also important to understand the psychological aspect to risk-taking and the motivations behind why such individuals partake in risk-related activities. Some researchers suggest that risk-inclined individuals feel that their lives are boring and constricted without risk (Lupton \& Tulloch, 2002). However, an in-depth understanding of risk-inclined individuals' decision-making process may be crucial to eventually understanding how risk affects their SWB. For instance, the risk tourist's motivation and desire to partake in risk activities while on vacation may fulfill an existing void, or reduce stress, in their life and therefore gives them happiness, positively contributing to their SWB (Han \& Patterson, 2007). Furthermore, research has indicated that "physically active leisure directly contribute[s] to higher levels of physical health and wellbeing, and lower levels of mental ill-health [...] outdoor-sport participation [is] beneficial to health, irrespective of the type of stress" (Han \& Patterson, 2007, p. 331).

The most prominent conceptual framework in the literature related to risk activity is edgework, which emerged out of the Marx-Mead theory that "suggests that the opposition between spontaneity and constraint is at the heart of many important problems that confront members of modern postindustrial society" (Lyng, 1990, p. 865). Lyng suggested that edgework should be understood as a reaction to the alienating influence of modern society in which individuals were socialized into reproducing constraining social practices. Edgework was thus conceptualized by Lyng (1990) to classify the risk related attributes of an individual's self-realization, selfactualization, and/or self-determination that challenged normative structures.

In order to gain a deeper understanding of risk-inclined individuals' personality and behavior, research has shown that risk takers, such as skydivers, are able to control their fear, which can lead to "positive self-evaluation and to an enhanced self-esteem" (Lipscombe, 1999, p. 281). Lipscombe (1999) found that veteran skydivers continue to jump because the experience 
elevates their functioning, emotional and physical, over a significant period of time. "Two decades of research has demonstrated that skydiving is a high stimulus, high risk activity [and] participants have been described as stimulus addicts, sensation seekers, thrill seekers, action seekers, and edgeworkers" (Lipscombe, 1999, p. 268). The literature has also indicated that voluntary risktaking leads to greater control over one's self and that risk takers are able to feel a sense of accomplishment by partaking in such activity (Lupton \& Tulloch, 2002), which further evidences the possibility that risk inclined individuals may have a higher SWB as a result of partaking in risk activities. It may be possible that their feelings of happiness (SWB) drive them to continue participation in risk activity.

\section{Conclusion and Implications for Future Inquiry}

The purpose of this review and synthesis was to evaluate whether or not common attributes exist between SWB (e.g. long-term happiness) and risk activities within risk-tourism. Upon reviewing the concepts, the most prevalent common attribute identified connecting these concepts was emotion. Diener (1996) found that "SWB comprises people's evaluative responses to their lives [...] both cognitive and emotional responses" (p. 390). Lipscombe found that "participants [who partake in risk activities] have been described as stimulus addicts, sensation seekers, thrill seekers, action seekers, and edgeworkers" (p. 268), all of which can trigger emotional responses.

While research has linked risk to happiness (SWB) through positive emotion (e.g. via positivist approaches) it has not linked risk to happiness through the negative emotion that the risk inclined individual may experience after partaking in the activity, nor has it explored how the individual overcomes any negative emotion experienced after partaking in the activity. For instance, a risk tourist may experience negative emotion because societal perceptions of the risk activities are negative, but they still partake in the risk activity because it makes them happy and adds value to their overall QOL. Additionally, it is possible that increased exposure to risk can lead to real injury, illness, and other negative consequences, which ultimately detract from an individual's wellbeing. Likewise, a negative emotion like fear may be mitigated by a positive emotion like excitement, before the individual engages in the activity. As such, the manner by which emotion is linked to SWB should not be viewed as static. The literature suggests that a risk inclined individual may evolve through a cyclical process of both positive and negative emotions prior to, during, and after the activity. Thus, the conditions under which such transitions toward positive and/or negative emotions occur warrant further investigation, to gain a deeper understanding of risk-tourists' responses in the cycle.

Moreover, since previous modes of inquiry have taken positivist approaches to establishing a causal relationship between risk and the outcome for individuals partaking in those activities, the conclusions of said research may be trivial. Positivist approaches may be problematic because positivism does not necessarily rely on negative facts. Thus, if the purpose of this study were to measure a risk tourist's SWB, the literature would only support assessing it on the grounds of positive emotion.

The review of existing work therefore suggests that positivist approaches have likely failed to link the concepts of risk and SWB entirely on the basis of emotion. As such, a marginal research gap remains: that one may only be able to measure the positive emotion associated with risk, not the negative, as doing so does not holistically connect the constructs of risk and SWB. As a result, the foundational premise of this review appears to be only partially supported by the existing evidence, based on the assumption that an individual is capable of assessing their happiness and/or satisfaction with life. The assumption is only supported through the positive emotion felt by risk 
inclined individual, but it is not yet known how any negative influences may be overcome. For instance, if negative societal influences cause an individual to feel concerned or insecure with their decision to participate in a risk activity, it is necessary to question why that individual would still participate. Moreover, it is important to question how that emotion is converted into happiness. Thus, future research efforts should explore the links between risk and SWB with regard to negative emotion, and how any negative emotion (as an outcome of risk activity) can still contribute to the individual's SWB (e.g. converted to happiness).

Finally, future research may use this review and synthesis as a basis to develop a theoretical model and collect data to establish the linking mechanisms between SWB and risk activity on the basis of emotion. Arguably, the link lies within the individual's appraisal and negotiation of risk. However, the limits of positivist techniques may require qualitative or mixed methods approaches to understand tourists' conceptions of risks and their negotiation of the risks over time and across multiple social and spatial domains. This can help to understand better how perceptions of risks change and how these may influence long-term affective and psychological states. Gaining a firmer grasp of these negotiations of risks and their impacts may also offer stronger predictors of future tourism and risk-related behaviors. This can subsequently inform the marketing of places for risk-inclined consumers, the development of specialist services and experiences for risktourists, and the management of risk-tourism in destinations. 


\section{References}

Allman, T. L., Mittelstaedt, R. D., Martin, B., \& Goldenberg, M. (2009). Exploring the motivations of BASE jumpers: Extreme sport enthusiasts. Journal of Sport \& Tourism, 14(4), 229-247.

Andereck, K. L., Valentine, K. M., Vogt, C. A., \& Knopf, R. C. (2007). A cross-cultural analysis of tourism and quality of life perceptions. Journal of Sustainable Tourism, 15(5), 483-502.

Bentley, T. A., Page, S. J., \& Edwards, J. (2008). Monitoring injury in the new zealand adventure tourism sector: An operator survey. Journal of Travel Medicine, 15(6), 395-403.

Bentley, T. A., \& Page, S. J. (2001). Scoping the extent of adventure tourism accidents. Annals of Tourism Research, 28(3), 705-726.

Berdychevsky, L., \& Gibson, H. (2015a). Women's sexual sensation seeking and risk taking in leisure travel. Journal of Leisure Research, 47(5), 621-646.

Berdychevsky, L., \& Gibson, H. J. (2015b). Sex and risk in young women's tourist experiences: Context, likelihood, and consequences. Tourism Management, 51, 78-90.

Berdychevsky, L., \& Gibson, H. J. (2015c). Phenomenology of young women's sexual risk-taking in tourism. Tourism Management, 46, 299-310.

Brymer, E., \& Oades, L. G. (2009). Extreme sports: A positive transformation in courage and humility. Journal of Humanistic Psychology, 49(1), 114-126.

Buckley, R. (2012). Rush as a key motivation in skilled adventure tourism: Resolving the risk recreation paradox. Tourism Management, 33(4), 961-970.

Butt, Z. I., Rashid, K., Mahanoor, T. A., Saeed, N., Adnan, M. A. J., \& Hashmi, S. (2016). Relationship Between Psychological Well Being and Exercise. Science International, 28(2), 1569-1574.

Campbell, A. (1976). Subjective measures of well-being. American Psychologist, 31(2), 117-124.

Cater, C. I. (2006). Playing with risk? Participant perceptions of risk and management implications in adventure tourism. Tourism Management, 27(2), 317-325.

Cecil, A. K., Yao-Yi, F., Suosheng, W., \& Avgoustis, S. (2010). Cultural tourism and quality of life: Results of a longitudinal study. European Journal of Tourism Research, 3(1), 54-66.

Csikszentmihályi, M. (2000). Beyond boredom and anxiety. San Francisco, CA: Jossey-Bass.

Csikszentmihályi, M. (2014). Flow and the foundations of positive psychology. Dordrecht: Springer.

Croes, R. (2016). Connecting tourism development with small island destinations and with the well-being of the island residents. Journal of Destination Marketing \& Management, 5(1), $1-4$.

Diener, E. (1994). Assessing subjective well-being: Progress and opportunities. Social Indicators Research, 31(2), 103-157.

Diener, E. (1996). Traits can be powerful, but are not enough: Lessons from subjective well-being. Journal of Research in Personality, 30(3), 389-399.

Diener, E., Oishi, S., \& Lucas, R. E. (2003). Personality, culture, and subjective well-being: Emotional and cognitive evaluations of life. Annual Review of Psychology, 54(1), 403-425.

Dolnicar, S., Yanamandram, V., \& Cliff, K. (2012). The contribution of vacations to quality of life. Annals of Tourism Research, 39(1), 59-83.

Eid, M., \& Larsen, R. J. (Eds.). (2008). The science of subjective well-being. New York, NY: Guilford Press.

Elsrud, T. (2001). Risk creation in traveling: Backpacker adventure narration. Annals of Tourism Research, 28(3), 597-617. 
Emmons, R. A. (1986). Personal strivings: An approach to personality and subjective well-being. Journal of Personality \& Social Psychology, 51(5), 1058-1068.

ESPN Action Sports. (2012). X-Games. Retrieved October 8, 2012 from: http://espn.go.com/action/xgames/summer/2012/index

Hallin, C. A., \& Mykletun, R. J. (2006). Space and place for BASE: On the evolution of a BASEjumping attraction image. Scandinavian Journal of Hospitality and Tourism, 6(2), 95-117.

Han, J., \& Patterson, I. (2007). An analysis of the influence that leisure experiences have on a person's mood state, health, and wellbeing. Annals of Leisure Research, 10(3-4), 328-351.

Hartwell, H., Fyall, A., Willis, C., Page, S., Ladkin, A., \& Hemingway, A. (In-press). Progress in tourism and destination wellbeing research. Current Issues in Tourism, 1-63.

Henderson, K. A. (2007). Quality of life and leisure education: Implications for tourism economies. World Leisure Journal, 49(2), 88-93.

Johnston, M. E. (1992). Facing the challenges: Adventure in the mountains of New Zealand. In Weiler, B., \& Hall, C. M. (Eds.), Special interest tourism (pp. 159-169). London: Belhaven Press.

Larsen, S., \& Brun, W. (2011). 'I am not at risk-typical tourists are'! Social comparison of risk in tourists. Perspectives in Public Health, 131(6), 275-279.

Lee, T., \& Crompton, J. (1992). Measuring novelty seeking in tourism. Annals of Tourism Research, 19(4), 732-751.

Lepp, A., \& Gibson, H. (2008). Sensation seeking and tourism: Tourist role, perception of risk and destination choice. Tourism Management, 29(4), 740-750.

Lipscombe, N. (1999). The relevance of the peak experience to continued skydiving participation: a qualitative approach to assessing motivations. Leisure Studies, 18(4), 267-288.

Lupton, D., \& Tulloch, J. (2002). 'Life would be pretty dull without risk': voluntary risk-taking and its pleasures. Health, Risk \& Society, 4(2), 113-124.

Lyng, S. (1990). Edgework: A social psychological analysis of voluntary risk taking. American Journal of Sociology, 95(4), 851-886.

Lyng, S. (Ed.). (2005). Edgework: The sociology of risk-taking. New York, NY: Routledge.

McCabe, S., Joldersma, T., \& Chunxiao, L. (2010). Understanding the benefits of social tourism: Linking participation to subjective well-being and quality of life. International Journal of Tourism Research, 12(6), 761-773.

Michalkó, G., \& Rátz, T. (2010). Measurement of tourism-oriented aspects of quality of life. Journal of Tourism Challenges \& Trends, 3(2), 35-50.

Mitchell, V. W. (1999). Consumer perceived risk: Conceptualisations and models. European Journal of Marketing, 33(1/2), 163-195.

Moscardo, G. (2009). Tourism and quality of life: Towards a more critical approach. Tourism \& Hospitality Research, 9(2), 159-170.

Neal, J. D., Sirgy, M. J., \& Uysal, M. (2004). Measureing the effect of tourism services on travelers' quality of life: further validation. Social Indicators Research, 69(3), 243-277.

Neal, J. D., Uysal, M., \& Sirgy, M. J. (2007). The effect of tourism services on travelers' quality of life. Journal of Travel Research, 46(2), 154-163.

Page, S. J. (2009). Current issue in tourism: The evolution of travel medicine research: A new research agenda for tourism? Tourism Management, 30(2), 149-157.

Pizam, A., Jeong, G. H., Reichel, A., van Boemmel, H., Lusson, J. M., Steynberg, L., \& Montmany, N. (2004). The relationship between risk-taking, sensation-seeking, and the 
tourist behavior of young adults: A cross-cultural study. Journal of Travel Research, 42(3), 251-260.

Priest, S., \& Bunting, C. (1993). Changes in perceived risk and competence during whitewater canoeing. Journal of Applied Recreation Research, 18(4), 265-280.

Priest, S., \& Carpenter, G. (1993). Changes in perceived risk and competence during adventurous leisure experiences. Journal of Applied Recreation Research, 18(1), 51-71.

Reisinger, Y., \& Mavondo, F. (2005). Travel anxiety and intentions to travel internationally: Implications of travel risk perception. Journal of Travel Research, 43(3), 212-225.

Rivera, M., Croes, R., \& Lee, S. (2016). Tourism development and happiness: A residents' perspective. Journal of Destination Marketing \& Management, 5(1), 5-15.

Ryan, C. (2003). Risk acceptance in adventure tourism - Paradox and context. In Wilks, J. \& Page, S. J. (Eds.) Managing Tourist Health and Safety in the New Millennium (pp. 55-65). Oxford: Pergamon.

Ryan, C., \& Kinder, R. (1996). Sex, tourism, and sex tourism: fulfilling similar needs? Tourism Management, 17(7), 507-518.

Ryff, C. D. (2014). Psychological well-being revisited: Advances in the science and practice of eudaimonia. Psychotherapy and Psychosomatics, 83(1), 10-28.

Ryff, C. D., \& Keyes, C. L. M. (1995). The structure of psychological well-being revisited. Journal of Personality and Social Psychology, 69(4), 719.

Schmutte, P. S., \& Ryff, C. D. (1997). Personality and well-being: reexamining methods and meanings. Journal of Personality and Social Psychology, 73(3), 549-559.

Shin, D. C., \& Johnson, D. M. (1978). Avowed happiness as an overall assessment of the Quality of life. Social Indicators Research, 5(4), 475-492.

Sirgy, M. J. (2010). Toward a quality-of-life theory of leisure travel satisfaction. Journal of Travel Research, 49(2), 246-260.

Stebbins, R. A. (2007). Serious leisure: A perspective for our time. New Brunswick, NJ: Transaction Publishers.

Tennant, R., Hiller, L., Fishwick, R., Platt, S., Joseph, S., Weich, S., Parkinson, J., Secker, J., \& Stewart-Brown, S. (2007). The Warwick-Edinburgh mental well-being scale (WEMWBS): development and UK validation. Health and Quality of life Outcomes, 5(1), 63.

Torres, E. N. (2016). Guest interactions and the formation of memorable experiences: An ethnography. International Journal of Contemporary Hospitality Management, 28(10), 2132-2155

Trauer, B. (2006). Conceptualizing special interest tourism-frameworks for analysis. Tourism Management, 27(2), 183-200.

Uriely, N. \& Belhassen, Y. (2006). Drugs and risk-taking in tourism. Annals of Tourism Research, 33(2), 339-359.

Vittersø, J. (2004). Subjective well-being Versus self-actualization: Using the flow-simplex to promote a conceptual clarification of subjective quality of life (English). Social Indicators Research, 65(3), 299-331.

Uriely, N., \& Belhassen, Y. (2006). Drugs and risk-taking in tourism. Annals of Tourism Research, 33(2), 339-359.

Wickens, E. (1997). Licensed for thrill: Risk-taking and tourism. In S. Clift and P. Gabowski (Eds.), Tourism and Health: Risks. Research and Responses (pp. 151-164). London: Pinter. 